\title{
Evaluation of the main oral manifestations associated with Down Syndrome:
}

\section{Integrative review}

\author{
Avaliação das principais manifestações orais associadas a Síndrome de Down: Revisão integrativa \\ Evaluación de las principales manifestaciones orales asociadas al Síndrome de Down: Revisión
}

integrativa

Received: 06/25/2021 | Reviewed: 07/01/2021 | Accept: 07/03/2021 | Published: 07/16/2021

\author{
Bruna Karen Pereira dos Santos \\ ORCID: https://orcid.org/0000-0003-2157-3978 \\ Centro Universitário Maurício de Nassau, Brazil \\ E-mail: brunakaren@gmail.com \\ Gislaine Suelen Lucena Silva \\ ORCID: https://orcid.org/0000-0003-1931-6825 \\ Centro Universitário Maurício de Nassau, Brazil \\ E-mail: gislainesuelen@gmail.com \\ Osório Queiroga de Assis Neto \\ ORCID: https://orcid.org/0000-0003-2293-9740 \\ Centro Universitário Maurício de Nassau, Brazil \\ E-mail: osorioassisneto@gmail.com \\ Jabes Gennedyr da Cruz Lima \\ ORCID: https://orcid.org/0000-0001-7420-7686 \\ Universidade Federal do Rio Grande do Norte, Brazil \\ E-mail: jabes.gennedyr@hotmail.com \\ Beatryz Maria Franco da Silva \\ ORCID: https://orcid.org/0000-0002-1910-557X \\ Universidade Federal do Rio Grande do Norte, Brazil \\ E-mail: beatryzfranco1993@gmail.com \\ Raphael Florentino Souza Barbalho de Medeiros \\ ORCID: https://orcid.org/0000-0002-7905-2596 \\ Universidade Federal do Rio Grande do Norte, Brazil \\ E-mail: raphaelflorentino20@gmail.com \\ Joaquim Felipe Junior \\ ORCID: https://orcid.org/0000-0001-9653-3386 \\ Universidade Potiguar, Brazil \\ E-mail: joaquim.felipe354@gmail.com \\ Marvin Felipe Oliveira \\ ORCID: https://orcid.org/0000-0002-2874-615X
Faculdade IDE, Brazil \\ E-mail: marvinfelipe156@gmail.com \\ Juliana Augusta Nascimento de Souza \\ ORCID: https://orcid.org/0000-0002-3025-8091 \\ Universidade Potiguar, Brazil \\ E-mail: julianasouzaodontologia@gmail.com \\ Victor Luiz Barbosa Zacarias \\ ORCID: https://orcid.org/0000-0002-3305-7949 \\ Universidade Federal do Rio Grande do Norte, Brazil \\ E-mail: victor.luiz@live.com \\ Juliana Campos Pinheiro \\ ORCID: https://orcid.org/0000-0001-5687-7635 \\ Universidade Tiradentes, Brazil \\ E-mail: dra.julianacpinheiro@gmail.com \\ Rafaella Bastos Leite \\ ORCID: https://orcid.org/0000-0002-3304-120X \\ Centro Universitário Maurício de Nassau, Brazil \\ E-mail: rrafaella_bastos@hotmail.com
}

\begin{abstract}
Down Syndrome or Trisomy of chromosome 21, as it is also known worldwide, is characterized by an error in chromosome distribution with the presence of an extra chromosome in the distal portion of it, generating specific physical and clinical characteristics throughout these people's lives. This paper aims to identify and discuss the main issues related to the role of oral health in the quality of life of people with Down syndrome. A search for papers was
\end{abstract}


carried out in the following electronic databases: BIREME and PubMed, between the years 2010 to 2020. The search for electronic databases retrieved 22 articles. After reading the title and abstract, reading in full and applying the inclusion and exclusion criteria, a total of 09 articles were selected. It is concluded that there are frequent oral alterations in people with Down syndrome and some of these can be observed and treated from the first months of the child's life. In this way, the present study contributes in a scientific way to the general knowledge of oral problems and frequent alterations in people with down syndrome and elucidates their means of prevention and dental treatments from early childhood as a way to improve the quality of life and well-being of these patients.

Keywords: Oral health; Dentistry; Down syndrome.

\section{Resumo}

A Síndrome de Down ou Trissomia do cromossomo 21, como também é mundialmente conhecida, é caracterizada por um erro na distribuição cromossômica com a presença de um cromossomo extra na porção distal do mesmo, gerando características físicas e clínicas específicas ao longo da vida dessas pessoas. O presente trabalho tem como objetivo identificar e discutir as principais questões relacionadas ao papel da saúde bucal na qualidade de vida de pessoas portadoras da Síndrome de Down. Realizou-se uma pesquisa de trabalhos nas seguintes bases de dados eletrônica: BIREME e PubMed, entre os anos de 2010 a 2020. A busca das bases eletrônicas recuperou 22 artigos. Após a leitura do título e resumo, leitura na integra e aplicação dos critérios de inclusão e exclusão foi selecionado um total de 09 artigos. Conclui-se que há alterações bucais frequentes em pessoas portadoras da Síndrome de Down e algumas dessas podem ser observadas e tratadas desde os primeiros meses de vida da criança. Desta forma, o presente estudo contribui de forma científica para o conhecimento geral de problemas e alterações bucais frequentes nas pessoas portadoras da síndrome de Down e elucida seus meios de prevenção e tratamentos odontológicos desde a primeira infância como forma de melhoria na qualidade de vida e bem-estar desses pacientes.

Palavras-chave: Saúde bucal; Odontologia; Síndrome de Down.

\section{Resumen}

El Síndrome de Down o Trisomía del cromosoma 21, como también se le conoce mundialmente, se caracteriza por un error en la distribución cromosómica con la presencia de un cromosoma extra en la porción distal del mismo, generando características físicas y clínicas específicas a lo largo de la vida de estas personas. Este artículo tiene como objetivo identificar y discutir los principales temas relacionados con el papel de la salud bucal en la calidad de vida de las personas con síndrome de Down. Se realizó una búsqueda de artículos en las siguientes bases de datos electrónicas: BIREME y PubMed, entre los años 2010 a 2020. La búsqueda de bases de datos electrónicas recuperó 22 artículos. Después de leer el título y el resumen, leerlo íntegramente y aplicar los criterios de inclusión y exclusión, se seleccionaron un total de 09 artículos. Se concluye que son frecuentes las alteraciones bucales en personas con síndrome de Down y algunas de ellas pueden ser observadas y tratadas desde los primeros meses de vida del niño. De esta forma, el presente estudio contribuye de forma científica al conocimiento general de los problemas bucales y las frecuentes alteraciones en las personas con síndrome de Down y dilucida sus vías de prevención y tratamientos dentales desde la primera infancia como una forma de mejorar la calidad de vida y el bienestar. siendo de estos pacientes.

Palabras clave: Salud bucal; Odontología; Síndrome de Down.

\section{Introduction}

Down syndrome was the first chromosomal malformation detected in man and currently the scientific literature indicates that it is the syndrome with chromosomal anomaly most present in the human race. Also known worldwide as trisomy 21 , down syndrome has as a determining factor the presence of an extra chromosome 21 in the distal portion of it. Regarding its etiology, this is not yet fully elucidated, with the hypothesis of advanced maternal age being reported as the most accepted (Nacamura, 2015; Garcia, 2019).

Down syndrome is characterized by an error in chromosomal distribution where there is no meiotic, mitotic or translocation disjunction and there is the presence of the extra chromosome already in the intrauterine phase, generating specific physical characteristics throughout this individual's life, such as eyes in an oblique position with internal commissures that diverge from each other, narrow palpebral fissure and large, thick lips with transverse folds. Given the presence of these phenotypic characteristics in the newborn, it is possible to conclude the diagnosis of Down syndrome. However, in prenatal care, ultrasound (USG) or biochemical tests allow confirming the diagnosis through samples taken from the chorionic villi or amniocentesis exam in order to diagnose changes associated with the baby's chromosomes (Nardes, 2017; Duarte, 2019) . 
Regarding clinical characteristics, patients with trisomy 21 have conoid teeth, change in dental eruptive chronology, agenesis, hypotonic tongue (directly interfering with correct tongue positioning), Angle class III, crossbite and mouth breathing leaving the mucosa dry and fissured oral cavity (Duarte, 2019). Among parents and caregivers, the doubts and difficulties when it comes to the oral health of children with trisomy 21 are notorious, and it is very important to advise them on the potential metabolic or cardiac risks of these patients when oral health is neglected (Ferreira, 2016).

Thus, it is necessary that dentists are scientifically grounded to perform their activities with the efficiency required by patients with down syndrome, and within this concept, this work aims to identify and discuss the main issues related to the role of oral health in the quality of life of people with Down syndrome. In this context, this study aims to identify and discuss the main issues related to the role of oral health in the quality of life of people with Down syndrome.

\section{Methodology}

The present study had an analytical, exploratory purpose, in the transversal category, defined by the inductive procedure, characterized by the described-comparative method with an indirect observation model. The research was carried out in the BIREME and PUBMED databases on April 2nd of this year. The universe of the study included articles hosted in the system, published between 2010 and 2020, which covered the descriptors "Oral Health; Dentistry; Down's syndrome".

Articles that contained the indicated descriptors, obeyed the deadline, as well as availability of the same in full, were included in the research. Works that had incomplete files, duplicate articles, as well as those that did not understand the research universe were excluded. Aiming at tracing a profile of oral health in patients with down syndrome, the research shows the benefit of discussing the data and results obtained in the articles studied, not causing biological risk, nor the risk of exposure and loss of personal data, since the data is outsourced. The search for electronic databases retrieved 22 articles. Given the criteria, 11 articles were collected, and after applying the selection criteria, 9 articles were used for evaluation, then they were organized, identified and listed, and they were reread, in order to carry out a more in-depth analysis. , directed by the guiding question.

\section{Results and Discussion}

The main results related to the most prevalent oral alterations in patients with Trisomy 21 are shown in Table 1 .

Table 1. Most prevalent oral alterations in patients with Trisomy 21.

\begin{tabular}{|l|l|}
\hline Macroglossia & Mouth breathing / Fissured Oral Mucosa \\
\hline Tooth Agenesis/Hypodontia & Microdontics \\
\hline Ogival Palate & Diastema / Dental Crowding \\
\hline Angle Class III Malocclusion & Change in Dental Eruptive Chronology \\
\hline Posterior Crossbite & Dental Cavity \\
\hline Previous Open Bite & Periodontal Disease \\
\hline
\end{tabular}

Source: Authors (2021).

Patients with intellectual disabilities such as down syndrome need extra care and supervision in their activities, especially related to oral health, as they are considered in a group where oral and dental pathology behaves more and more intensely than normal (Diéguez- Pérez, 2016).

There is controversy in the scientific literature about the tongue of patients with trisomy 21 , some studies report that 
the tongue has a normal size and the oral cavity of this patient is smaller than the size considered normal due to maxillary atrophy and for this reason the tongue is not it lodges comfortably inside the oral cavity, showing the impression of an enlarged tongue. Other studies report that the increase in the size of the tongue is due to muscle hypotonia, making it more flaccid and thus making it larger (Macroglossia) (Nacamura, 2015).

Thus, it directly interferes with phonation, swallowing, feeding and causes a wrong accommodation of the tongue inside the oral cavity, causing a malocclusion usually Angle Class III, anterior open bite, posterior crossbite, vestibularization of the incisors and deleterious oral habits, as difficulties for lip sealing, mouth breathing that, consequently, leaves irritated and often cracked lips, high palate and, in general, increases the susceptibility to the installation of infectious processes (Nacamura, 2015).

The harm that malocclusion causes to these children requires a multidisciplinary intervention to treat the multiple disorders described above and to obtain improvements in the results of these treatments, such as the use of electrical stimulation through a therapist, for example. These children need to be offered consultations in order to eliminate or improve language dysfunction in early childhood, in the breastfeeding phase. And, when possible, preventive orthodontic treatment or corrective treatment when there is already an installed malocclusion, such as dental crowding, because after its correction, oral hygiene is facilitated (Duarte, 2019).

Borges (2011) carried out a study that proves the relationship between the functional capacity of facial muscles and the respiratory profile of children with down syndrome, in addition to losing control of the organs responsible for the TMJ, changing mouth opening and closing, emphasizes that mouth breathing intensifies the difficulty in the general motor coordination of these patients, making physical therapy intervention necessary to contribute to the achievement of muscle strength and function, improving the overall health and well-being of children with Down syndrome.

According to Javed (2018) there is also controversy regarding the description of the palate of children with down syndrome, it is commonly described as arched and restricted, but his research reports new data, highlighting normality in the hard palate of children between their first months of life, making -if less compared to described normal and healthy palates. An analysis was carried out showing that $60 \%$ of patients with Down's Syndrome never felt pain from a dental cause, but the vast majority of patients had undergone dental prophylaxis and application of fluoride in the office at least once and the vast majority brush teeth two to three times a day, when they perform this activity alone, there is supervision by their guardians. Such patients had frequent habits such as mouth breathing, sucking or grinding the fingers, dry mouth, halitosis and gingival bleeding, in descending order. Tooth agenesis was observed in $26.7 \%$ of patients and hypoplasia did not appear (Peinado, 2018).

The risk of caries may increase due to salivary changes, but the increase in salivary $\mathrm{pH}$, the delay in the chronology of dental eruption and the diastemas present in patients with down syndrome have a significant relationship with the low prevalence of caries activity when compared to general population. In the absence of correct oral hygiene due to the lack of manual dexterity of these patients, treatment can be done preventively with the application of fissure sealant to help prevent or avoid invasive and time-consuming treatments for the treatment of caries in the future (Isabelle, 2019; Duarte, 2019).

A study carried out proves that children with Down syndrome are less affected by tooth decay, on the other hand, they have worse gingival health with a high level of inflammation and probing depth when compared to children without the syndrome. In addition to Class III malocclusion, the presence of occlusal wear, bruxism, hypodontia, fissured tongue, microdontia of the upper lateral incisors were frequently observed, and developmental delay and tooth eruption should be provided. to prevent and limit the severity of such observed pathologies (Diéguez-Pérez, 2016).

Periodontal disease rapidly affects down syndrome patients due to their deficient systemic and immunological condition and has no prevalence, it affects both primary and permanent dentition, thus requiring an intervention from basic oral 
hygiene instruction to complex and continuous treatment . For surgical procedures, antibiotic prophylaxis with the opinion of a cardiologist is important. To aid prophylaxis, mouthwashes with $012 \%$ chlorhexidine gluconate, automatic toothbrushes, fluoride pastes and periodic scrapings are included. A patient with Trisomy 21 may be treated by dentists in a clinical setting as long as the necessary care is taken. When the procedure is unsuccessful, treatment under general anesthesia is indicated (Isabelle, 2019; Berthold, 2004).

\section{Conclusion}

The study proves that there are frequent oral changes in people with Down syndrome, such as macroglossia, tooth agenesis, hypodontia, high palate, malocclusion, dry and fissured mucosa, microdontia, diastema, crowding, change in dental eruptive chronology, mouth breathing, caries dental and periodontal disease. Some of these changes can be observed in the first months of the child's life, and therefore treatments can be started with the aim of alleviating its worsening. Therefore, it is important to emphasize the importance of parents and guardians providing dental care from early childhood and continuing periodically throughout life, in order to minimize the impacts on the oral health of children with Down syndrome.

Doubts and difficulties regarding the oral health of patients with down syndrome by parents and caregivers were highlighted, making the presence of a professional essential to alert and clarify the risks caused by the lack of it in children with down syndrome, thus encouraging the maintenance of good oral hygiene as a way to prevent diseases and promote oral health.

\section{References}

Borges, C. S. S. (2011). Uma avaliação acerca da correlação do perfil respiratório com a capacidade funcional dos musculos da face de crianças com síndrome de down. Saúde.com, 7(2), 109-115.

Berthold, T. B. (2004). Síndrome de Down: aspectos gerais e odontológicos. R. Ci méd. biol, 3(2), 252-260.

Duarte, M. J. S. (2019). A importância da odontopediatria na melhoria da qualidade de vida de crianças com trissomia 21. 2019. 27p. Tese (Mestrado integrado em medicina dentária) - Universidade Fernando Pessoa, Faculdade de Porto.

Diéguez-Pérez, M. (2016). Oral health in children with physical (Cerebral Palsy) and intellectual (Down Syndrome) disabilities: Systematic review I. J Clin Exp Dent, 8(3), 337-343.

Ferreira, R. (2016). Promoção de Saúde Bucal e Síndrome de Down: Inclusão e Qualidade de Vida por meio da Extensão Universitária. Odontologia, 24(48), 54-53.

Garcia, L. F. M. (2009). Levantamento epidemiológico de indivíduos com características sindrômicas de aneuploidias: prevalência da síndrome de down. Disciplinarum Scientia, 10(1), 1-10.

Isabelle, J. (2019). Condicões periodontais de pacientes portadores de síndrome de down. Monografia (Graduação em Odontologia), Centro Universitário São Lucas, 2019.

Javed, F. (2018). Outcme of orthodontic palatal plate therapy for orofacial dysfunction in children with Down syndrome: A systematic review. Orthod Craniofac Res, 21(1), 20-26.

Nacamura, C. A. (2015). Síndrome de down: inclusão no atendimento odontológico municipal. FOL, 25(1), 27-35.

Nardes, A. B. (2017). Entendendo e ensinando sobre Síndrome de Down. Raízes e Rumos, 5(1), 223-228.

Peinado, N. R. (2018). A study of the dental treatment needs os special patients: cerebral paralysis and Down syndrome. Eur J Paediatr Dent, 19(3), 233-238. 